Meta

Journal des traducteurs

Translators' Journal

\title{
Legal Translation Research: Looking Back and Moving Forward
}

\section{Fernando Prieto Ramos}

Volume 60, numéro 2, août 2015

$60^{\mathrm{e}}$ anniversaire. Les horizons de la traduction : retour vers le futur

$60^{\text {th }}$ Anniversary. Translation's Horizons: Back to the Future

60mo aniversario. Los horizontes de la traducción: regreso al futuro

URI : https://id.erudit.org/iderudit/1032917ar

DOI : https://doi.org/10.7202/1032917ar

Aller au sommaire du numéro

Éditeur(s)

Les Presses de l’Université de Montréal

ISSN

0026-0452 (imprimé)

1492-1421 (numérique)

Découvrir la revue

Citer ce document

Prieto Ramos, F. (2015). Legal Translation Research: Looking Back and Moving Forward. Meta, 60(2), 366-366. https://doi.org/10.7202/1032917ar d'utilisation que vous pouvez consulter en ligne.

https://apropos.erudit.org/fr/usagers/politique-dutilisation/ 


\title{
Legal Translation Research: Looking Back and Moving Forward
}

\author{
Fernando Prieto Ramos \\ Université de Genève, Geneva, Switzerland \\ fernando.prieto@unige.ch
}

Since Meta (1979) published its first volume ever devoted to legal translation, this field has become one of the most prominent examples of interdisciplinary development within Translation Studies. The remarkable expansion of Legal Translation Studies (LTS) in the past few decades explains the interest in stocktaking in order to better define its common denominators and a collective vision for the future.

On the basis of a study carried out from this perspective (Prieto Ramos 2014), the key elements of LTS's disciplinary specificity will be reviewed through the different stages leading to the field's current position and its particular interaction with Law. The focus will be placed on the common ground of its research community as a means to identifying distinctive features and avenues for further development: object of study, historical development, academic position, denominations and perspectives. The categorization of legal texts and the analysis of legal contextual variables will be highlighted as essential in defining the scope of the discipline and in tailoring methodological approaches.

Indeed, the development of specific methods continues to be of critical importance to disciplinary specificity. Most approaches converge on the need to integrate legal theories and comparative legal analysis into legal translation methodology and research. While LTS paradigms have become increasingly sophisticated in examining the components of that integration, the synthesis into overarching operational models remains a priority. This is particularly relevant in the case of research on the relation between decision-making, specialized competence and legal translation quality, especially if LTS is to further contribute to raising standards in professional practice.

Fernando Prieto Ramos is Full Professor of Translation and Director of the Centre for Legal and Institutional Translation Studies (Transius) at the University of Geneva's Faculty of Translation and Interpreting. With a background in both Translation and Law, his work focuses on legal and institutional translation, including interdisciplinary methodologies, international legal instruments and specialized terminology. A former member of the Centre for Translation and Textual Studies at Dublin City University, he has received several research and teaching awards, including a European Label Award for Innovative Methods in Language Teaching from the European Commission and an ERC-SNSF Consolidator Grant. He has also translated for several organizations since 1997, including five years as an in-house translator at the WTO. 